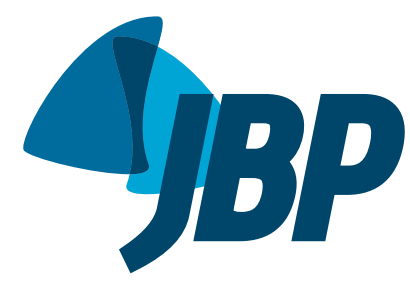

1. Departamento de Fisioterapia, Universidade Federal dos Vales do Jequitinhonha e Mucuri - UFVJM Diamantina (MG) Brasil.

2. Programa de Pós-Graduação em Reabilitação e Desempenho Funcional, Universidade Federal dos Vales do Jequitinhonha e Mucuri - UFVJM Diamantina (MG) Brasil.

3. Programa de Pós-Graduação em Ciências da Reabilitação, Universidade Federal de Minas Gerais, Belo Horizonte (MG) Brasil.

4. Departamento de Fisioterapia, Universidade Federal de Minas Gerais, Belo Horizonte (MG) Brasil.

5. School of Physical and Occupational Therapy, McGill University, Montreal, OC, Canada.

6. Respiratory Epidemiology and Clinical Research Unit, Research Institute of McGill University Health Center, Montreal, OC, Canada.

Submitted: 29 August 2018.

Accepted: 1 April 2019

Study carried out in the Laboratório de Avaliação e Pesquisa do Desempenho Cardiorrespiratório - LabCARE

- Departamento de Fisioterapia, Universidade Federal de Minas Gerais UFMG - Belo Horizonte (MG) Brasil.

\section{Reference values for the Unsupported Upper Limb Exercise test in healthy adults in Brazil}

\author{
Vanessa Pereira Lima ${ }^{1,2}(\mathbb{D})$, Marcelo Velloso ${ }^{3,4}$ (i) , Bruno Porto Pessoa ${ }^{3,4}(\mathbb{C}$, \\ Fabiana Damasceno Almeida ${ }^{3,4}$, Giane Amorim Ribeiro-Samora ${ }^{3,4}$, \\ Tania Janaudis-Ferreira ${ }^{5,6}$ (D)
}

\begin{abstract}
Objective: To establish reference values for the Unsupported Upper Limb EXercise (UULEX) test, which measures peak arm exercise capacity, in healthy adults in Brazil. Methods: This was a cross-sectional study, involving presumably healthy individuals $\geq$ 30 years of age who completed questionnaires and underwent spirometry. All of the individuals underwent two UULEX tests 30-min apart. The outcome measure was the maximum time (in min) to completion of the test. Results: We included 100 individuals between 30 and 80 years of age. The mean test completion time was $11.99 \pm 1.90 \mathrm{~min}$ among the women and $12.89 \pm 2.15$ min among the men $(p=0.03)$. The test completion time showed statistically significant correlations with age $(r=-0.48 ; p<0.001)$, gender $(r=0.28 ; p=0.004)$, body mass index (BMI, $r=-0.20 ; p=0.05)$, and height $(r=0.28$; $p=0.005)$. Linear regression analysis showed that the predictors of UULEX completion time were age $(p=0.000), B M I(p=0.003)$, and gender $(p=0.019)$, which collectively explained $30 \%$ of the total variability. The mean UULEX completion time was $6 \%$ lower for the women than for the men. Conclusions: The present study was able to establish reference values for the UULEX test in healthy adults in Brazil. The values were influenced by age, gender, and BMI.
\end{abstract}

Keywords: Reference values; Exercise test; Upper extremity.

\section{INTRODUCTION}

Peripheral muscle dysfunction is one of the most common extrathoracic manifestations of COPD and has been associated with poor prognosis. ${ }^{(1)}$ Studies have shown that a reduction in muscle mass and strength is a predictor of mortality ${ }^{(2,3)}$ and a marker of exacerbation risk in COPD patients. ${ }^{(4)}$ The cause of peripheral muscle dysfunction is multifactorial, the main factors involved being physical inactivity, malnutrition, exacerbations, and corticosteroid use. ${ }^{(5)}$ Although leg muscles are more affected than are arm muscles, ${ }^{(5,6)}$ COPD patients have great difficulty performing activities of daily living that involve the arms, especially those that involve unsupported arms. During such activities, there is an increase in oxygen consumption and greater use of the ventilatory reserve. (7) In addition, there is thoracoabdominal asynchrony, a decrease in inspiratory capacity, ${ }^{(6,8)}$ and an increase in the levels of lactic acid, worsening the sensation of dyspnea. ${ }^{(9)}$ Therefore, these individuals perform activities that involve the arms at a lower intensity compared with their healthy peers. ${ }^{(10)}$

Arm muscle training should be part of pulmonary rehabilitation programs. ${ }^{(11)}$ Studies have shown an improvement in exercise capacity, ${ }^{(12,13)}$ dyspnea, ${ }^{(14)}$ and arm function ${ }^{(13)}$ after a specific physical training program. A simple, inexpensive test that has been used to assess arm exercise capacity in clinical trials and rehabilitation programs is the Unsupported Upper Limb EXercise (UULEX) test. ${ }^{(15)}$ The UULEX test is a standardized symptom-limited incremental test that assesses peak unsupported arm exercise capacity. ${ }^{(15)}$ The movements made during the test reflect the arm movements made during daily tasks, which makes the test have great clinical application. This test is valid and reliable in COPD patients. ${ }^{(15,16)}$

The UULEX test has the potential to be used even in healthy individuals. No ceiling effect has been reported and test-retest reliability is good in this population. ${ }^{(17)}$ Nevertheless, to date, no reference values have been

Correspondence to:

Vanessa Pereira Lima. Campus JK, Rodovia MGT 367, km 583, 5000, Alto da Jacuba, CEP 39100-000, Diamantina, MG, Brasil.

Financial support: This study received financial support from the Fundação de Amparo à Pesquisa do Estado de Minas Gerais (FAPEMIG, Foundation for the Support of Research in the State of Minas Gerais) and the Coordenação de Aperfeiçoamento de Pessoal de Nivel Superior (CAPES, Office for the Advancement of Higher Education). 
established for the UULEX test in the Brazilian population. These values would help determine the degree of dysfunction and understand the problems related to activities of daily living that involve unsupported arms among individuals with COPD or other clinical conditions, such as orthopedic(18) or neurological (19) impairments. In addition, they would serve as parameters for assessment of response to pulmonary rehabilitation programs.

The objective of the present study was to establish reference values for the UULEX test in a sample of healthy adults in Brazil.

\section{METHODS}

This was an observational cross-sectional study conducted in the Universidade Federal de Minas Gerais (UFMG, Federal University of Minas Gerais) Department of Physical Therapy Laboratory for the Evaluation of and Research on Cardiopulmonary Performance, located in the city of Belo Horizonte, Brazil. Participants were recruited through posters, electronic messages, and advertisements targeting the internal and external community of the UFMG. The inclusion criteria were as follows: being between 30 and 89 years of age; having no history of chronic disease; having no limitation of shoulder or arm movements that might impair test performance; having no symptomatic heart or lung disease; having normal spirometry results; being able to read and speak Portuguese; and reporting being healthy (a healthy person was defined as one who can perform his or her activities of daily living without limitations).(20) The exclusion criteria were as follows: having recently undergone a surgical procedure that prevented him or her from undergoing the study protocol; having a history of smoking; or being over 65 years of age and having a Mini-Mental
State Examination score below 13 (for those who were illiterate), below 18 (for those with a low or medium level of education) or below 26 (for those with a high level of education). ${ }^{(21)}$

The study was approved by the UFMG Research Ethics Committee (CAAE no. 47887415.6.0000.5149). All participants gave written informed consent.

\section{Measurement instruments}

\section{Unsupported Upper Limb EXercise test}

The UULEX test was performed as described by Takahashi et al. ${ }^{(15)}$ To perform the test, the participant sat on a chair facing a board $(120 \mathrm{~cm}$ in height $x$ $84 \mathrm{~cm}$ in width) with eight 8-cm-wide color bands, which were $5 \mathrm{~cm}$ apart (Figure 1). The participant remained seated throughout the test. The first level was set at knee-height. The participant received a PVC tube weighing $0.2 \mathrm{~kg}$. The test started with the participant warming up for 2 min, moving his or her arms from the pelvic girdle to the first level on the board, located at knee-height. After the warm-up period, the participant moved to the next level on the board (level 2), performing the same movement for 1 min. The level was changed every minute. When the maximum vertical height, that is, level 8 on the board, was reached, the $0.2-\mathrm{kg}$ PVC tube was replaced by a $0.5-\mathrm{kg}$ one and the participant should continue the exercise by moving the tube from the pelvic girdle to level 8 on the board, without stopping at the other levels, for $1 \mathrm{~min}$. From this time point onward, the tube was replaced by a $0.5-\mathrm{kg}$ heavier one every minute until a maximum of $2.0 \mathrm{~kg}$ was reached. The test was performed at a steady pace, at a metronome-controlled cadence of $30 \mathrm{bpm}$. Throughout the test, the participant was encouraged to continue the exercise as long as possible until exhaustion. Participants were not allowed

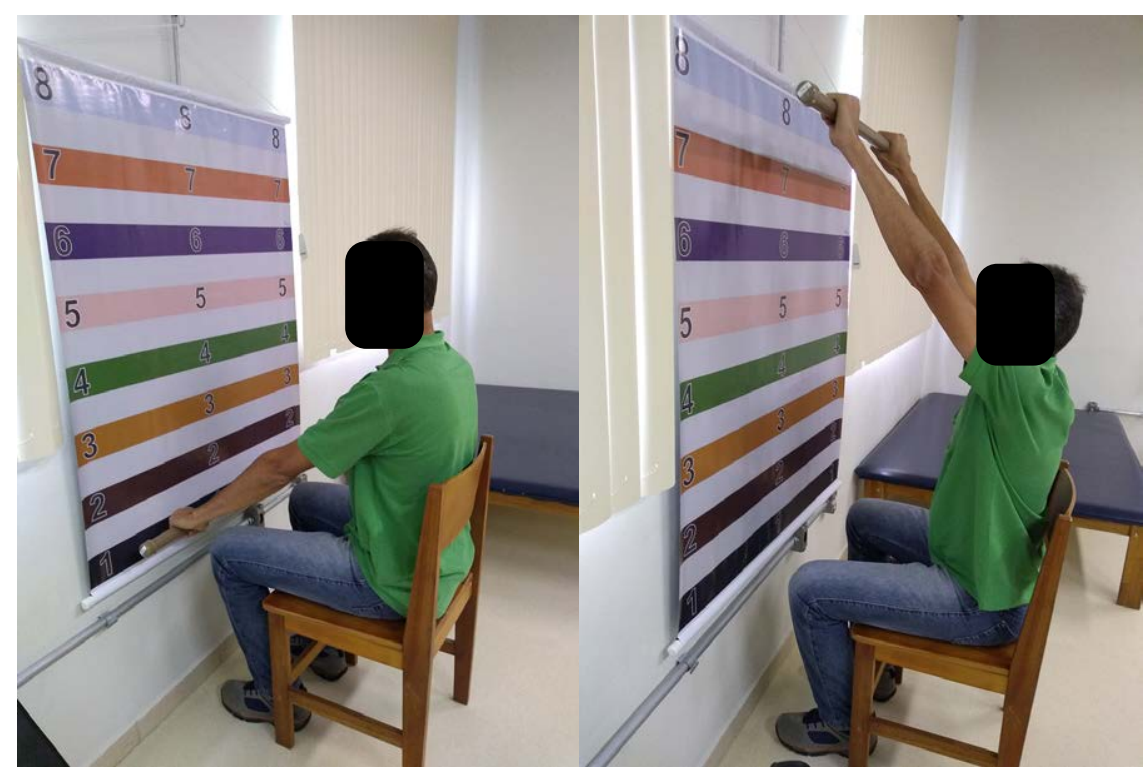

Figure 1. Volunteer performing the test. 
to stop during the test; if this happened, the test was ended. The test interruption criteria were as follows: requesting to stop the test; not performing the full arc of motion; or being unable to keep up with the metronome pace. The maximum test duration was 15 min; if the volunteer completed 15 min of test, the test was ended. This value was chosen because the mean test duration was $14.21 \mathrm{~min}$ in a previous study of healthy individuals. ${ }^{(22)}$ The outcome measure was the maximum time (in $\mathrm{min}$ ) to completion of the test, that is, a longer time equals a better result.

\section{Human Activity Profile}

The Human Activity Profile (HAP) instrument has been cross-culturally adapted for use in Brazil. ${ }^{(23)}$ The HAP is used to assess the level of physical activity in both healthy individuals and individuals with a medical condition. It consists of 94 items presented in ascending numerical order, from the lowest energy expenditure activity (1) to the highest energy expenditure activity (94). For each item, there are three possible answers: "I am currently able to perform the activity"; "I have stopped performing the activity"; or "I have never performed the activity". From the answers given, a maximal activity score (MAS) is derived, representing the highest oxygen-demanding activity that the individual is still able to perform. Then, an adjusted activity score (AAS) is calculated by subtracting from the MAS the number of activities with lower energy requirements that the individual has stopped performing. According to the AAS, the participants were classified as inactive (AAS < 53 points), moderately active (53 $\leq$ AAS $\leq$ $74)$, or active (AAS > 74). ${ }^{(23)}$

\section{Body mass index}

The body mass index (BMI) was calculated by the formula weight $(\mathrm{kg}) /$ height $^{2}\left(\mathrm{~m}^{2}\right)$. Weight was measured with an anthropometric scale (Filizola, São Paulo, Brazil). Height was measured with the scale's stadiometer. For this measurement, participants were placed in a standing position, barefoot, with the feet parallel, the heels together, and the arms hanging at the sides. The head was positioned so that the lower part of the eye socket was in the same plane as the outer ear hole. On the basis of the results, participants were classified in accordance with the Brazilian Guidelines for the Management of Obesity. ${ }^{(24)}$

\section{Pulmonary function}

Pulmonary function was assessed by spirometry (Koko spirometer; PDS Instrumentation Inc., Louisville, CO, USA). Spirometric measurements were performed by a qualified technician, in accordance with the American Thoracic Society standards. ${ }^{(25)}$ FVC and $\mathrm{FEV}_{1}$ were calculated from the flow-volume curve and were expressed as absolute values (in L) and as a percentage of predicted values. The $\mathrm{FEV}_{1} / \mathrm{FVC}$ ratio was also recorded. The reference values used were those for the Brazilian population. ${ }^{(26)}$

\section{Procedures}

Participants were evaluated on a single day. After written informed consent was obtained, demographic data, including gender, age, and anthropometric measurements, were collected. Participants were then administered the PAH questionnaire. Subsequently, to ensure that participants did not have lung disease, they underwent spirometry. After a 10-min rest period, the test session was started. All participants underwent two UULEX tests 30 min apart.

\section{Statistical analysis}

Sample size was calculated as recommended by Ceriotti et al. ${ }^{(27)}$

Data are presented as means and standard deviations. Continuous variables were assessed for normality of distribution with the Shapiro-Wilk test. Bivariate associations were assessed with Pearson's correlation test. Variables were selected for inclusion in the multiple linear regression model on the basis of correlation analysis. A value of $p<0.05$ was used as the criterion for including a variable, and a value of $p>0.10$ was used as the criterion for excluding it. The multiple linear regression model was built in a stepwise fashion. The final model was determined by the adjusted coefficient of determination $\left(r^{2}\right)$ and by statistical significance. The existence of multicollinearity was analyzed using variance inflation factors $(>0.2)$ and tolerance $(<5)$, and the distribution of residuals was tested for normality using Q-Q plots. To determine the lower limit of normal (LLN), the following formula was devised:

$L L N=$ value predicted by the linear regression equation $-(1.64 \times$ standard error of the estimate)

The level of significance was set at $p<0.05$. Statistical analyses were performed with the IBM SPSS Statistics software package, version 19.0 (IBM Corporation, Armonk, NY, USA).

\section{RESULTS}

We included 100 individuals in the study, 52 of whom were male. The mean age was $55.87 \pm 14.67$ years, and the mean BMI was $26.59 \pm 3.75 \mathrm{~kg} /$ $\mathrm{m}^{2}$. All participants had normal pulmonary function. The spirometric values expressed as a percentage of predicted values were as follows: FVC $=95.12 \pm$ 12.74\%; $\mathrm{FEV}_{1}=94.38 \pm 13.51 \%$; and $\mathrm{FEV}_{1} / \mathrm{FVC}$ ratio $=96.69 \pm 8.30 \%$. Seventy percent of the participants were classified as active by the PAH. Table 1 shows the anthropometric and demographic characteristics of the participants by gender and age group.

The mean UULEX completion time was $11.99 \pm 1.90$ min among the women and $12.89 \pm 2.15$ min among the men $(p=0.03)$; that is, the mean test completion time was $6 \%$ lower for the women than for the men. The test completion time showed statistically significant correlations with age $(r=-0.48 ; p<0.001)$, gender $(r=0.28 ; p=0.004)$, BMI $(r=-0.20 ; p=0.05)$, 
and height $(r=0.28 ; p=0.005)$ but not with weight ( $r=0.08 ; p=0.41)$ or level of physical activity $(r$ $=0.12 ; p=0.22)$. Linear regression analysis of the observed correlations showed that the predictors of UULEX completion time were age $(p<0.001)$, BMI ( $p$ $=0.003)$, and gender $(p=0.019)$, which collectively explained $30 \%$ of the total variability $\left(r^{2}=0.30 ; p\right.$ $<0.005)$.

UULEX (time in $\mathrm{min})=1,079.96+(43.531 \times[0$ woman; 1 man $])-(2.96 \times$ age $)-(7.45 \times B M I)$

Table 2 shows the mean, minimum, and maximum time (in min) to completion of the UULEX test in the sample by gender.

\section{DISCUSSION}

This was the first study to establish reference values for the UULEX test in individuals over 30 years of age in Brazil.

Our results show a negative relationship between test completion time and age. Younger individuals had better test results. Lima et al.,(28) in a study of 104 healthy individuals over 30 years of age, presented reference values for another test that assesses arm endurance and reported that age was the sole determinant of better performance. Another study assessed arm functional capacity in adults and elderly individuals and showed a negative association between age and test performance. ${ }^{(29)}$ Aging is known to be accompanied by declines in bodily functioning, the most important of which is loss of muscle mass and strength. ${ }^{(9)}$ These declines start around age 30, and there is an estimated annual loss of muscle mass of $0.1-0.5 \%$ after this age. ${ }^{(30)}$ These factors may explain the findings of the present study.

Another variable that showed a negative relationship with test completion time was BMI. Previous studies on reference values for other tests that assess functional capacity have reported this association. ${ }^{(31,32)}$ However, a study that assessed arm function using the six-minute pegboard and ring test, the purpose of which is to move as many rings as possible in $6 \mathrm{~min}$, found no correlation between test performance and BMI. ${ }^{(33)}$ These findings differ from those in the present study; however, we should take into consideration that the sample of that study was younger (mean age of 23.41 \pm 3.58 years among the men and $23.27 \pm 3.0$ years among the women) and had a lower BMI (25.09 \pm $3.91 \mathrm{~kg} / \mathrm{m}^{2}$ among the men and $22.26 \pm 2.36 \mathrm{~kg} /$ $\mathrm{m}^{2}$ among the women), which may have affected the results. In the present study, the mean age overall was $55.87 \pm 14.67$ years, and the mean BMI was $26.59 \pm 3.75 \mathrm{~kg} / \mathrm{m}^{2}$, classified as overweight. ${ }^{(24)}$ Aging is accompanied by an increase in muscle fiber fat tissue and accumulation of subcutaneous fat, which is a negative predictor of muscle quality, as well as

Table 1. Anthropometric and demographic characteristics of the 100 participants by gender and age group. ${ }^{a}$

\begin{tabular}{|c|c|c|c|c|c|c|}
\hline $\begin{array}{c}\text { Gender } \\
\text { Age group, years }\end{array}$ & $\mathbf{n}$ & Age, years & Height, m & Weight, kg & BMI, $\mathrm{kg} / \mathrm{m}^{2}$ & AAS \\
\hline \multicolumn{7}{|l|}{ Women } \\
\hline $31-40$ & 8 & $33.00 \pm 2.64$ & $1.69 \pm 0.08$ & $69.62 \pm 6.74$ & $24.51 \pm 3.46$ & $90.00 \pm 3.43$ \\
\hline $41-50$ & 10 & $46.70 \pm 2.62$ & $1.63 \pm 0.10$ & $67.99 \pm 11.09$ & $25.39 \pm 4.05$ & $84.40 \pm 8.27$ \\
\hline $51-60$ & 9 & $54.67 \pm 3.24$ & $1.57 \pm 0.44$ & $66.00 \pm 7.49$ & $26.64 \pm 3.08$ & $75.11 \pm 8.62$ \\
\hline $61-70$ & 10 & $66.70 \pm 2.26$ & $1.55 \pm 0.03$ & $67.13 \pm 10.21$ & $27.69 \pm 4.15$ & $72.00 \pm 10.70$ \\
\hline $71-80$ & 11 & $76.00 \pm 2.36$ & $1.53 \pm 0.07$ & $69.23 \pm 10.70$ & $29.27 \pm 3.65$ & $73.73 \pm 8.74$ \\
\hline \multicolumn{7}{|l|}{ Men } \\
\hline $31-40$ & 11 & $35.73 \pm 2.61$ & $1.82 \pm 0.09$ & $87.69 \pm 11.18$ & $26.44 \pm 2.45$ & $88.73 \pm 6.73$ \\
\hline $41-50$ & 11 & $46.18 \pm 2.72$ & $1.72 \pm 0.05$ & $81.30 \pm 4.86$ & $27.46 \pm 1.87$ & $89.91 \pm 4.34$ \\
\hline $51-60$ & 11 & $56.45 \pm 3.26$ & $1.71 \pm 0.07$ & $76.11 \pm 10.90$ & $26.03 \pm 3.43$ & $83.82 \pm 9.33$ \\
\hline $61-70$ & 9 & $65.00 \pm 3.50$ & $1.71 \pm 0.08$ & $75.07 \pm 23.25$ & $25.20 \pm 6.20$ & $78.78 \pm 14.06$ \\
\hline $71-80$ & 10 & $75.30 \pm 2.16$ & $1.71 \pm 0.06$ & $78.22 \pm 14.53$ & $26.40 \pm 3.50$ & $78.20 \pm 8.23$ \\
\hline
\end{tabular}

BMI: body mass index; and AAS: adjusted activity score. aValues expressed as mean \pm SD.

Table 2. Mean, minimum, and maximum time (in $\mathrm{min}$ ) to completion of the Unsupported Upper Limb EXercise test by gender, as well as the lower limit of normal calculated using the regression model.

\begin{tabular}{|c|c|c|c|c|}
\hline \multirow[t]{2}{*}{ Age group, years } & \multicolumn{2}{|c|}{ Women $(n=48)$} & \multicolumn{2}{|c|}{ Men $(n=52)$} \\
\hline & Time, min & LLN $^{a}$ & Time, min & LLN $^{\mathrm{a}}$ \\
\hline $31-40$ & $13.99(12.20-15.00)$ & 11.51 & $14.24(13.19-15.00)$ & 11.75 \\
\hline $41-50$ & $13.40(12.15-15.00)$ & 10.92 & $14.10(10.32-15.00)$ & 11.62 \\
\hline $51-60$ & $12.50(9.48-15.00)$ & 10.01 & $13.26(9.00-15.00)$ & 10.78 \\
\hline $61-70$ & $11.72(9.36-13.20)$ & 9.23 & $13.05(9.00-15.00)$ & 10.56 \\
\hline $71-80$ & $11.66(9.01-13.51)$ & 9.18 & $12.47(8.17-15.00)$ & 9.98 \\
\hline
\end{tabular}

LLN: lower limit of normal. SEE: standard error of the estimate $=91.04$. ${ }^{\text {aLLN }}=$ mean test completion time $-(1.64$ $\times \mathrm{SEE})$. UULEX completion time $(\mathrm{min})=1,079.96+(43.531 \times[0$ woman, 1 man $])-(2.96 \times$ age $)-(7.45 \times$ body mass index). $r^{2}=0.30$. 
by disturbances in muscle metabolism, leading to a decrease in oxidative capacity and capillary density in obese individuals, which explains poorer performance on the test with increasing BMI. ${ }^{(34)}$

Women performed more poorly compared with men in all age groups. On average, men performed $6 \%$ better. The UULEX test requires manual dexterity, motor coordination, and strength. According to the literature, manual dexterity and motor coordination are not associated with gender, ${ }^{(28)}$ which indicates that strength may be responsible for the differences found in the present study. Men have greater muscle mass and a lower fat percentage and, consequently, more strength. In addition, men have more efficient aerobic and anaerobic energy production. ${ }^{(35)}$

The limitations of our study are related to the fact that we were unable to obtain a sample of individuals over 80 years of age, mainly because of the large number of comorbidities present in this age group that met the exclusion criteria. This may limit the external validity for this age group. In addition, the low $r^{2}$ value and the fact that the equation was not tested in an independent sample are limitations of the study. However, it is not uncommon to find low $r^{2}$ values in the literature on reference values. ${ }^{(32,36,37)}$ To our knowledge, this is the first study involving a large sample of the Brazilian population that has sought to establish reference values for the UULEX test.

In conclusion, the present study was able to establish reference values for the UULEX test in a sample of healthy adults in Brazil. The reference values were influenced by age, gender, and BMI. These values will allow the identification of impairments in peak arm exercise capacity in people with different arm functional limitations. These data will be useful both in clinical practice, for measuring the results of pulmonary rehabilitation programs, and in the undertaking of clinical research in the area.

\section{REFERENCES}

1. Clini EM, Ambrosino N. Impaired arm activity in COPD: a questionable goal for rehabilitation. Eur Respir J. 2014;43(6):1551-3. https://doi. org/10.1183/09031936.00002414

2. Marquis K, Debigaré $R$, Lacasse $Y$, Leblanc $P$, Jobin J, Carrier G, et al. Midthigh muscle cross-sectional area is a better predictor of mortality than body mass index in patients with chronic obstructive pulmonary disease. Am J Respir Crit Care Med. 2002;166(6):809-13. https://doi. org/10.1164/rccm.2107031

3. Swallow EB, Reyes D, Hopkinson NS, Man WD, Porcher R, Cetti EJ, et al. Quadriceps strength predicts mortality in patients with moderate to severe chronic obstructive pulmonary disease. Thorax. 2007;62(2):115-20. https://doi.org/10.1136/thx.2006.062026

4. Vilaró J, Ramirez-Sarmiento A, Martínez-Llorens JM, Mendoza T, Alvarez M, Sánchez-Cayado N, et al. Global muscle dysfunction as a risk factor of readmission to hospital due to COPD exacerbations. Respir Med. 2010;104(12):1896-902. https://doi.org/10.1016/j. rmed.2010.05.001

5. Barreiro $\mathrm{E}$, Gea J. Respiratory and limb muscle dysfunction in COPD. COPD. 2015;12(4):413-26. https://doi.org/10.3109/15412555.2014.9 74737

6. Miranda EF, Malaguti C, Corso SD. Peripheral muscle dysfunction in COPD: lower limbs versus upper limbs. J Bras Pneumol. 2011;37(3):380-8. https://doi.org/10.1590/S180637132011000300016

7. Velloso M, Stella SG, Cendon S, Silva AC, Jardim JR. Metabolic and ventilatory parameters of four activities of daily living accomplished with arms in COPD patients. Chest. 2003;123(4):1047-53. https://doi. org/10.1378/chest.123.4.1047

8. McKeough ZJ, Alison JA, Bye PT. Arm positioning alters lung volumes in subjects with COPD and healthy subjects. Aust J Physiother. 2003;49(2):133-7. https://doi.org/10.1016/S0004-9514(14)60129-X

9. de Souza GF, Castro AA, Velloso M, Silva CR, Jardim JR. Lactic acid levels in patients with chronic obstructive pulmonary disease accomplishing unsupported arm exercises. Chron Respir Dis. 2010;7(2):75-82. https://doi.org/10.1177/1479972310361833

10. Meijer K, Annegarn J, Lima Passos V, Savelberg HH, Schols AM, Wouters EF, et al. Characteristics of daily arm activities in patients with COPD. Eur Respir J. 2014;43(6):1631-41. https://doi. org/10.1183/09031936.00082513

11. Spruit MA, Singh SJ, Garvey C, ZuWallack R, Nici L, Rochester C, et al. An official American Thoracic Society/European Respiratory Society statement: key concepts and advances in pulmonary rehabilitation. Am J Respir Crit Care Med. 2013;188(8):e13-64.

12. Janaudis-Ferreira T, Hill K, Goldstein R, Wadell K, Brooks D. Arm exercise training in patients with chronic obstructive pulmonary disease: a systematic review. J Cardiopulm Rehabil Prev. 2009;29(5):277-83. https://doi.org/10.1097/HCR.0b013e3181b4c8d0
13. Janaudis-Ferreira $T$, Hill $K$, Goldstein RS, Robles-Ribeiro $P$ Beauchamp MK, Dolmage TE, et al. Resistance arm training in patients with COPD: A Randomized Controlled Trial. Chest. 2011;139(1):151-8. https://doi.org/10.1378/chest.10-1292

14. McKeough ZJ, Velloso M, Lima VP, Alison JA. Upper limb exercise training for COPD. Cochrane Database Syst Rev. 2016;11:CD011434. https://doi.org/10.1002/14651858.CD011434.pub2

15. Takahashi T, Jenkins SC, Strauss GR, Watson CP, Lake FR. A new unsupported upper limb exercise test for patients with chronic obstructive pulmonary disease. J Cardiopulm Rehabil. 2003;23(6):430-7. https://doi.org/10.1097/00008483-20031100000007

16. Janaudis-Ferreira T, Beauchamp MK, Goldstein RS, Brooks D. How should we measure arm exercise capacity in patients with COPD? A systematic review. Chest. 2012;141(1):111-120. https://doi. org/10.1378/chest.11-0475

17. Lima VP, Velloso M, Almeida FD, Carmona B, Ribeiro-Samora GA Janaudis-Ferreira $T$. Test-retest reliability of the unsupported upperlimb exercise test (UULEX) and 6-min peg board ring test (6PBRT) in healthy adult individuals. Physiother Theory Pract. 2018;34(10):806812. https://doi.org/10.1080/09593985.2018.1425786

18. Baltzer $\mathrm{H}$, Novak CB, McCabe SJ. A scoping review of disabilities of the arm, shoulder, and hand scores for hand and wrist conditions J Hand Surg Am. 2014;39(12):2472-80. https://doi.org/10.1016/j. jhsa.2014.07.050

19. Baker K, Barrett L, Playford ED, Aspden T, Riazi A, Hobart J. Measuring arm function early after stroke: is the DASH good enough? J Neurol Neurosurg Psychiatry. 2016;87(6):604-10. https:// doi.org/10.1136/jnnp-2015-310557

20. Pasqualetti G, Gori G, Blandizzi C, Del Tacca M. Healthy volunteers and early phases of clinical experimentation. Eur $\mathrm{J}$ Clin Pharmacol 2010;66(7):647-53. https://doi.org/10.1007/s00228-010-0827-0

21. Bertolucci PH, Brucki SM, Campacci SR, Juliano Y. The Mini-Mental State Examination in a general population: impact of educational status [Article in Portuguese]. Arq Neuropsiquiatr. 1994;52(1):1-7. https://doi.org/10.1590/S0004-282X1994000100001

22. Oliveira A, Cruz J, Jácome C, Marques A. The Unsupported Upper Limb Exercise Test in People Without Disabilities: Assessing the Within-Day Test-Retest Reliability and the Effects of Age and Gender. Physiother Can. 2018;70(1):11-21. https://doi.org/10.3138/ ptc. 2016-42

23. Souza AC, Magalhães Lde C, Teixeira-Salmela LF. Crosscultural adaptation and analysis of the psychometric properties in the Brazilian version of the Human Activity Profile Cad Saude Publica. 2006;22(12):2623-36. https://doi.org/10.1590/S0102 311X2006001200012

24. Associação Brasileira para o Estudo da Obesidade e da Síndrome 
Metabólica (ABESO). Diretrizes brasileiras de obesidade. 4th ed. São Paulo: ABESO; 2016

25. Miller MR, Hankinson J, Brusasco V, Burgos F, Casaburi R, Coates A, et al. Standardisation of spirometry. Eur Respir J. 2005;26(2):319-38. https://doi.org/10.1183/09031936.05.00034805

26. Pereira CA, Sato T, Rodrigues SC. New reference values for forced spirometry in white adults in Brazil. J Bras Pneumol. 2007;33(4):397406. https://doi.org/10.1590/S1806-37132007000400008

27. Ceriotti $F$, Hinzmann R, Panteghini M. Reference intervals: the way forward. Ann Clin Biochem. 2009;46(Pt 1):8-17. https://doi. org/10.1258/acb.2008.008170

28. Lima VP, Almeida FD, Janaudis-Ferreira T, Carmona B, Ribeiro-Samora $\mathrm{G}$, Velloso M. Reference values for the six-minute pegboard and ring test in healthy adults in Brazil. J Bras Pneumol. 2018;44(3):190-194. https://doi.org/10.1590/s1806-37562017000000388

29. Michaelsen SM, Ovando AC, Natalio MA, Mazo GZ, Rodrigues LC. Upper extremity evaluation test trough TEMPA: Reference values, age, gender, dominance effect and relation to dexterity [Article in Portuguese]. Motricidade. 2011;7(2):47-55. https://doi.org/10.6063/ motricidade.7(2). 110

30. Liguori I, Russo G, Aran L, Bulli G, Curcio F, Della-Morte D, et al. Sarcopenia: Assessment of disease burden and strategies to improve outcomes. Clin Interv Aging. 2018;13:913-927. https://doi. org/10.2147/CIA.S149232

31. Dourado VZ, Guerra RL, Tanni SE, Antunes LC, Godoy I. Reference values for the incremental shuttle walk test in healthy subjects: from the walk distance to physiological responses. J Bras Pneumol. 2013;39(2):190-7. https://doi.org/10.1590/S180637132013000200010

32. Britto RR, Probst VS, de Andrade AF, Samora GA, Hernandes $N A$, Marinho PE, et al. Reference equations for the six-minute walk distance based on a Brazilian multicenter study. Brazilian J Phys Ther. 2013;17(6):556-63. https://doi.org/10.1590/S141335552012005000122

33. Ohara DG, Melo CS, Reis IM, Jamami M. Functional capacity assessment of upper limbs in healthy young adult subjects. Fisio Ter. 2017:30(1):159-67. http://dx.doi.org/10.1590/1980-5918.030.001 ao17 https://doi.org/10.1590/1980-5918.030.001.ao17

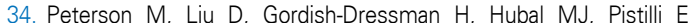
Angelopoulos T. Adiposity attenuates muscle quality and the adaptive response to resistance exercise in non-obese, healthy adults. Int J Obes (Lond). 2011;35(8):1095-103. https://doi.org/10.1038/ ijo.2010.257

35. Sandbakk $\varnothing$, Solli GS, Holmberg HC. Sex Differences in World Record Performance: The Influence of Sport Discipline and Competition Duration. Int J Sports Physiol Perform. 2018;13(1):2-8. https://doi. org/10.1123/ijspp.2017-0196

36. Pessoa IM, Houri Neto M, Montemezzo D, Silva LA, Andrade AD, Parreira VF. Predictive equations for respiratory muscle strength according to international and Brazilian guidelines. Braz J Phys Ther 2014:18(5):410-8. https://doi.org/10.1590/bjpt-rbf.2014.0044

37. Miyamoto K. The 6-min walk test. Respir Circ. 2014;62(7):697-703. 